\title{
Studies of the large intestine of sheep
}

\section{Nitrogen kinetics in sheep given chopped lucerne (Medicago sativa) hay*}

\author{
BY R. M. DIXON AND J. V. NOLAN
}

\author{
Department of Biochemistry and Nutrition, Faculty of Rural Science, \\ University of New England, Armidale, NSW 2351, Australia
}

(Received 27 September 1982-Accepted 30 June 1983)

1. A study was made of nitrogen kinetics in the large intestine of sheep given $800 \mathrm{~g}$ chopped lucerne (Medicago sativa) hay/d. Four sheep were continuously infused with $\left({ }^{15} \mathrm{NH}_{4}\right)_{2} \mathrm{SO}_{4}$ into the caecum and three other sheep were infused intravenously with $\left[{ }^{15} \mathrm{~N}\right]$ urea. A digesta marker, ${ }^{51} \mathrm{Cr}$ complexed with EDTA $\left({ }^{51} \mathrm{Cr}\right.$-EDTA), was infused into the rumen of each sheep to allow estimation of the rates of flow of digesta constituents. Infusions were continued until tracer concentrations reached plateaux in digesta and blood pools, after which the sheep were anaesthetized and slaughtered.

2. Pre-infusion samples and samples on plateau were obtained before slaughter for subsequent analysis to give plasma urea and rumen ammonia- $\mathrm{N}$ concentration and enrichment. At slaughter, digesta were obtained from the ileum and segments of the large intestine. These were analysed for ${ }^{51} \mathrm{Cr}$-EDTA content and concentration and enrichment of ammonia-N, microbial $\mathrm{N}$ and non-urea non-ammonia-N (NU-NAN).

3. N flows in segments of the large intestine were calculated and represented in a quantitative eight-pool model.

4. Transfer of plasma urea across the wall of the caecum and proximal colon was negligible but there was an input of $0.8 \mathrm{~g}$ endogenous NU-NAN/d.

5. Flow of urea plus ammonia- $\mathrm{N}$ in digesta from the ileum into the caecum contributed $1.0 \mathrm{~g} \mathrm{~N} / \mathrm{d}$ to the caecal ammonia pool.

6. Proteolysis and deamination produced a further $3.0 \mathrm{~g}$ ammonia-N/d in the caecum and proximal colon.

7. The net absorption of $\mathrm{N}$ between the ileum and the rectum was $2.8 \mathrm{~g} \mathrm{~N} / \mathrm{d}$ but $3.0 \mathrm{~g}$ ammonia- $\mathrm{N} / \mathrm{d}$ was absorbed from the caecum and proximal colon and, in addition, at least $0.9 \mathrm{~g}$ ammonia- $\mathrm{N} / \mathrm{d}$ from the distal colon and rectum.

8. Ammonia-N was incorporated into caecal microbes $(0.6 \mathrm{~g} \mathrm{~N} / \mathrm{d})$ and approximately $57 \%$ of the NU-NAN in caecal digesta was microbial $\mathbf{N}$. The majority of the microbial $\mathbf{N}$ flowing from the caecum was excreted in faeces.

9. The rate of irreversible loss of urea- $N$ from plasma, measured by intravenous infusion of $\left[{ }^{15} \mathrm{~N}\right] \mathrm{urea}$, was $13.6 \mathrm{~g} / \mathrm{d}$. On average 83 (SE 6.8)\% of the ${ }^{15} \mathrm{NH}_{3}$ apparently absorbed from the caecum was incorporated into plasma urea; caecal ammonia contributed $9-19 \%$ of the $\mathrm{N}$ in plasma urea and $0 \cdot 2-3 \cdot 1 \%$ of the $\mathrm{N}$ in rumen ammonia.

Present knowledge of the kinetics of nitrogen in the large intestine of sheep is based primarily on measurements of the concentration of nitrogenous constituents of digesta (Elsden et al. 1946; Williams, 1965) and their net disappearance, either between the ileum and rectum (e.g. Beever et al. 1976, 1977) or within parts of the large intestine (Dixon \& Nolan, 1982). Direct information on the sources of ammonia, and on ammonia absorption and urea entry, is restricted to in vitro studies (Hecker, $1971 a, b$ ) and the preliminary in vivo ${ }^{15} \mathrm{~N}$ studies of Nolan et al. (1976).

In the present study, sheep were continuously infused into the caecum with $\left({ }^{15} \mathrm{NH}_{4}\right)_{2} \mathrm{SO}_{4}$ or intravenously with [ $\left.{ }^{15} \mathrm{~N}\right] \mathrm{urea}$. This allowed estimates to be made, respectively, of the kinetics of ammonia in the caecum and proximal colon and of urea in the body. Flows of $\mathrm{N}$ between these and other $\mathrm{N}$ pools were also estimated. The results were used to develop a model of the flows of $\mathrm{N}$ between pools in the large intestine and the blood.

* Parts 1 and 2 appeared in the British Journal of Nutrition (1982), 47, 289-300 and 301-309 respectively. 
EX PE R I ME NT A L

Sheep and tracer infusions

Seven Merino wethers (3-4 years; $30-35 \mathrm{~kg}$ ) were housed indoors and given $800 \mathrm{~g}$ chopped lucerne (Medicago sativa) hay/d at hourly intervals as described previously (Dixon \& Nolan, 1982). Before the infusions of tracers were commenced, samples of blood and digesta were taken from all the animals and analysed to give the natural abundance or background concentrations of the isotope tracers. Four of the sheep with cannulas into the rumen and caecum had been used in a previous study (Dixon \& Nolan, 1982) and these were infused intra-caecally with $\left({ }^{15} \mathrm{NH}_{4}\right)_{2} \mathrm{SO}_{4}\left(96\right.$ atoms $\% ; 0.5-1.3 \mathrm{mg}$ atoms ${ }^{15} \mathrm{~N}$ in 1.1-1.2 1 water/d; Expt 1). Three other animals from the same group (one had a rumen and a caecal cannula; the other two had no gut cannulas) were infused intravenously with $\left[{ }^{15} \mathrm{~N}\right]$ urea $\left(96\right.$ atoms $\% ; 2.9 \mathrm{mg}$ atoms ${ }^{15} \mathrm{~N}$ in $0.08-0.1210 .15 \mathrm{M}$-sodium chloride/d; Expt 2). The five sheep which had rumen cannulas were also infused intraruminally with ${ }^{51} \mathrm{Cr}$ complexed with EDTA ( ${ }^{51} \mathrm{Cr}$-EDTA; $20 \mu \mathrm{Ci}, 10 \mathrm{mg} \mathrm{Cr}$-EDTA in $500 \mathrm{ml}$ water/d) at the same time as the infusions of ${ }^{15} \mathrm{~N}$. The infusions into individual animals were carried out intermittently over a period of 12 months.

Infusions were continued for the following times; ${ }^{51} \mathrm{Cr}$-EDTA $4300 \mathrm{~min},\left({ }^{15} \mathrm{NH}_{4}\right)_{2} \mathrm{SO}_{4}$ $1100 \mathrm{~min},\left[{ }^{15} \mathrm{~N}\right]$ urea $2100 \mathrm{~min}$. Other similar experiments (R. M. Dixon, unpublished results) involving continuous infusions of $\left({ }^{15} \mathrm{NH}_{4}\right)_{2} \mathrm{SO}_{4}$ into the caecum or $\left[{ }^{15} \mathrm{~N}\right]$ urea into the blood and sampling of caecal ammonia and blood urea at intervals for $2100 \mathrm{~min}$ suggested that these infusion times were sufficient to reach plateau tracer concentration. During the last 180 min of infusion, three blood samples were obtained from the jugular vein, and three samples of rumen fluid by suction through a small cage covered with nylon gauze and suspended in the ventral sac of the rumen. As described previously (Dixon \& Nolan, 1982), the infusions were then stopped and the sheep anaesthetized. Various segments of the gut were tied off and sampling of digesta was commenced immediately. The concentration of the indigestible, non-absorbable marker ${ }^{51} \mathrm{Cr}$-EDTA in each segment was used in calculation of flows of digesta and, hence, the flows of dry matter and nitrogenous substances in each sampled gut segment.

\section{Analytical methods}

The methods used for analysis of ${ }^{51} \mathrm{Cr}$-EDTA, ammonia, total $\mathrm{N}$ and urea concentrations have been described (Dixon \& Nolan, 1982).

A washed microbial fraction was obtained from digesta from the ileum and segments of the large intestine by differential centrifugation (Nolan \& Leng, 1972).

The enrichments with ${ }^{15} \mathrm{~N}$ of ammonia- $\mathrm{N}$, total $\mathrm{N}$, microbial $\mathrm{N}$ and urea- $\mathrm{N}$ were measured using a mass spectrometer(Model MS10; GEC-AEI(Electronics) Ltd, Manchester, England) according to the procedures and precautions described by Nolan \& Leng (1974) and Kempton et al. (1979). The enrichment of the non-urea non-ammonia-N (NU-NAN) in digesta was calculated from knowledge of the $\mathrm{N}$ concentrations in each fraction and the measured enrichments of total $\mathrm{N}$, ammonia- $\mathrm{N}$ and urea-N. It was assumed that the enrichment of $\mathrm{N}$ in urea in ileal digesta, which was not determined, was the same as for $\mathrm{N}$ in plasma urea.

\section{Calculations}

The ${ }^{15} \mathrm{~N}$ enrichment values were adjusted to an infusion rate of $5 \mathrm{mg}$ atoms ${ }^{15} \mathrm{~N} / \mathrm{d}$. The plateau enrichment was measured in digesta obtained at slaughter or, in the case of rumen digesta and plasma, in samples obtained $0-3 \mathrm{~h}$ before slaughter.

Flow of ${ }^{15} \mathrm{~N}$ through each gut segment was calculated from the enrichment of flow of each 
nitrogenous component. For the two sheep used in Expt 2 that did not receive ${ }^{51} \mathrm{Cr}$-EDTA infusions, the flow of dry matter in each gut segment was assumed to equal the mean flow in the other five sheep.

The rate of irreversible loss of tracee from primary pools (i.e. the pools into which tracer was infused) and the fraction of tracee in secondary pools derived from primary pools were calculated as described by Nolan \& Leng (1974).

The fraction of the caecal ammonia- $\mathrm{N}$ absorbed from the large intestine that was incorporated into the blood urea, estimated during intra-caecal $\left({ }^{15} \mathrm{NH}_{4}\right)_{2} \mathrm{SO}_{4}$ infusion, was given by:

Amount of absorbed ${ }^{15} \mathrm{~N}$ incorporated during urea synthesis

Apparent absorption of ${ }^{15} \mathrm{~N}$ from the large intestine

The apparent absorption of ${ }^{15} \mathrm{~N}$ from the large intestine was given by:

$$
\left\{\begin{array}{l}
\text { Infusion rate of } \\
{ }_{15} \mathrm{NH}_{3} \text { into the caecum } \\
\left(\mathrm{mg} \text { atoms }{ }^{15} \mathrm{~N} / \mathrm{d}\right)
\end{array}\right\}+\left\{\begin{array}{l}
{ }^{15} \mathrm{~N} \text { recycled to the } \\
\text { caecum via the ileum } \\
\left(\mathrm{mg} \text { atoms }{ }^{15} \mathrm{~N} / \mathrm{d}\right)
\end{array}\right\}-\left\{\begin{array}{l}
{ }^{15} \mathrm{~N} \text { excretion } \\
\text { in faeces } \\
\left(\mathrm{mg} \text { atoms }{ }^{15} \mathrm{~N} / \mathrm{d}\right)
\end{array}\right\}
$$

The rate of incorporation of ${ }^{15} \mathrm{~N}$ (mg atoms/d) into plasma urea during infusion of $\left({ }^{15} \mathrm{NH}_{4}\right)_{2} \mathrm{SO}_{4}$ into the caecum was given by:

$$
\left\{\begin{array}{l}
\text { Enrichment of plasma urea-N } \\
\left(\mathrm{mg} \text { atoms }{ }^{15} \mathrm{~N} / \mathrm{mol}\right. \text { urea-N) }
\end{array}\right\} \times\left\{\begin{array}{l}
\text { Rate of irreversible loss } \\
\text { measured with }\left[{ }^{15} \mathrm{~N}\right] \text { urea } \\
\text { (mol urea/d) }
\end{array}\right\}
$$

The proportion of microbial $\mathrm{N}$ in the NU-NAN in digesta was calculated as follows (cf. Beever et al. 1974):

$$
\frac{\text { Enrichment of digesta NU-NAN on plateau }}{\text { Enrichment of microbial N on plateau }} .
$$

\section{Model development}

The estimated rates of flow of ${ }^{15} \mathrm{~N}$ through the sampled segments of the large intestine and between the large intestine and the plasma were used to construct a quantitative model of $\mathrm{N}$ kinetics. The large intestine was represented as a series of segments each containing steady-state pools of ammonia-N and NU-NAN, the outflow in digesta from any pool $j$ being the inflow into the next pool $(j+1)$. The ${ }^{15} \mathrm{~N}$ input into the NU-NAN pool $(j+1)$ was calculated as the flow of ${ }^{15} \mathrm{~N}$-labelled NU-NAN through pool $j$, or in the case of the caecal NU-NAN pool the flow of ${ }^{15} \mathrm{~N}$-labelled NU-NAN through the ileum. It was assumed that any non-urea endogenous $\mathrm{N}$ entering via the gut wall did not contain ${ }^{15} \mathrm{~N}$ and that loss of ${ }^{15} \mathrm{~N}$ could only occur either by flow as ${ }^{15} \mathrm{~N}$-labelled NU-NAN to the $(j+2)$ NU-NAN pool or by flow to the $(j+1)$ ammonia pool. The ${ }^{15} \mathrm{~N}$ input into the $(j+1)$ ammonia pool was calculated as the flow of ${ }^{15} \mathrm{~N}$ through ammonia pool $j$, plus the apparent loss of ${ }^{15} \mathrm{~N}$ from the $(j+1)$ NU-NAN pool not accounted for by flow to the $(j+2)$ NU-NAN pool. It was assumed that blood $\left[{ }^{15} \mathrm{~N}\right]$ urea could directly enter each ammonia pool and that ${ }^{15} \mathrm{~N}$ could be lost from the $(j+1)$ ammonia pool either by flow to the $(j+2)$ ammonia pool or by direct absorption through the gut wall. Since some ${ }^{15} \mathrm{~N}$ that was absorbed from the large intestine was recycled to the caecum via ileal digesta, the total flow of ${ }^{15} \mathrm{~N}$ into the caecal ammonia pool was given by the rate of infusion of ${ }^{15} \mathrm{~N}$ into the caecal pool plus the flow of recycled ${ }^{15} \mathrm{~N}$ in urea and ammonia in ileal digesta.

Mathematical solutions giving values for two-way flows of $\mathrm{N}$ between ammonia in each of the gut segments and plasma urea were obtained by the following procedures. If in pool $j$, the rate of absorption of tracee as ammonia- $\mathrm{N}$ is designated by $a_{j}$ and the input of tracee 
as urea-N by $b_{j}$, and $E_{j}$ is the enrichment of ammonia-N in pool $j$ and $E_{b}$ is the enrichment of blood urea- $\mathrm{N}$, then absorption of ${ }^{15} \mathrm{NH}_{3}$ from pool $j=a_{j} \times E_{j}$ and, similarly, transfer of $\left[{ }^{15} \mathrm{~N}\right]$ urea from the blood to pool $j=b_{j} \times E_{b}$.

Since both absorption of ammonia- $\mathrm{N}$ and secretion of blood urea occur at the same time, under steady-state conditions, net absorption of tracee $\mathrm{N}=a_{j}-b_{j}$, and net absorption of ${ }^{15} \mathrm{~N}=a_{j} \times E_{j}-b_{j} \times E_{b}$. The calculated value for the net absorption of ${ }^{15} \mathrm{~N}$ is equal to the apparent loss of ${ }^{15} \mathrm{NH}_{3}$ and ${ }^{15} \mathrm{~N}$-labelled NU-NAN from gut segment $j$ given by the difference between the amount entering segment $j$ in digesta (or by infusion) and that leaving in digesta. Since Expts 1 and 2 give independent values for the flows of ${ }^{15} \mathrm{~N}$, two equations containing $a_{j}$ and $b_{j}$ can be defined and solved to give values for $a_{j}$ and $b_{j}$.

In steady-state the net flow of tracee between each NU-NAN and ammonia pool is that required to balance flows of $\mathrm{N}$ to and from the ammonia pool in that segment. The flow into the associated NU-NAN pool as endogenous non-urea-N is therefore that required to balance the flows into and out of each NU-NAN pool after accounting for $\mathrm{N}$ entering and leaving in digesta. (These calculations are described further on p. 765.)

Because NU-NAN enrichments in the spiral colon and descending colon were not measured in Expt 2, complete descriptions of the rates of flow of $\mathrm{N}$ were obtainable only for the caecum and the proximal colon in this model.

\section{Statistical analysis}

A two-way analysis of variance was used to test differences between ${ }^{15} \mathrm{~N}$ enrichments (or ${ }^{15} \mathrm{~N}$ flows) in segments of the large intestine. Means were separated into their respective classes using the 5\% Studentized Range (Snedecor \& Cochran, 1967). A $t$ test was used to test differences between Expts 1 and 2 in concentrations in various pools and flow rates between these pools.

RESULTS

\section{Ammonia and urea kinetics}

Concentrations of ammonia in the caecum and rumen fluid and urea in the plasma of sheep are given in Table 1. There were no significant differences in the concentrations between Expts 1 and 2.

The enrichments of $\mathbf{N}$ in ammonia in segments of the gut and in plasma urea during ${ }^{15} \mathrm{~N}$ infusions into the caecum or the blood are given in Fig. 1. The rates of irreversible loss of ammonia (Table 1) indicate that at least $2 \cdot 1-4 \cdot 2 \mathrm{~g}$ ammonia-N/d entered the caecal ammonia pool. A progressive decrease in enrichment of ammonia- $\mathrm{N}$ between the caecum and rectum indicated that unlabelled ammonia also entered the more distal parts of the large intestine (Fig. 1).

There was a decrease in flow of ${ }^{15} \mathrm{NH}_{3}$ in digesta between the caecum and rectum (Fig. 2) and $98 \%$ of the ${ }^{15} \mathrm{NH}_{3}$ passing out of the caecum did not arrive at the rectum. Furthermore, there was no corresponding increase in flow of ${ }^{15} \mathrm{~N}$-labelled NU-NAN as digesta passed from the proximal colon to the rectum (Fig. 4, see p. 763), indicating that the majority of the infused ${ }^{15} \mathrm{NH}_{3}$ that disappeared was absorbed from the gut and was not incorporated into micro-organisms. The fractions of plasma urea- $\mathrm{N}$ and rumen ammonia- $\mathrm{N}$ derived from caecal ammonia ranged from 9 to $19 \%$ and from 0.3 to $3.1 \%$ respectively (Table 1).

During the intravenous infusion of $\left[{ }^{15} \mathrm{~N}\right] \mathrm{urea}$, the enrichment of ammonia- $\mathrm{N}$ in the ileum was significantly greater $(P<0.05)$ than that in the caecum, but there was negligible difference between the enrichments of ammonia- $\mathrm{N}$ in different segments of the large intestine; the mean enrichment was $25 \%$ of that of plasma urea-N (Fig. 1).

The rate of irreversible loss of urea- $\mathrm{N}$ from the blood was $13.4-13.9 \mathrm{~g} / \mathrm{d}$. Plasma urea 


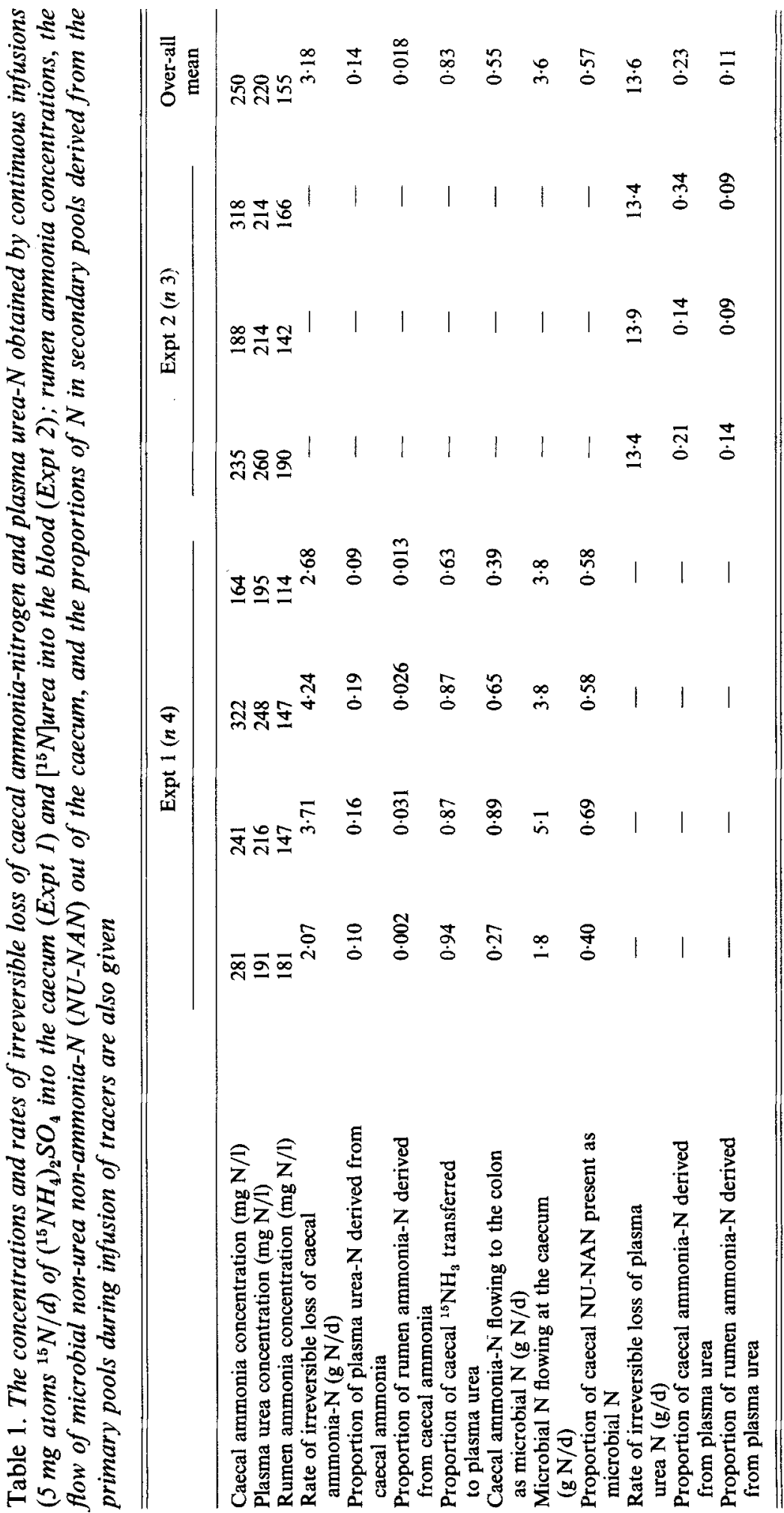



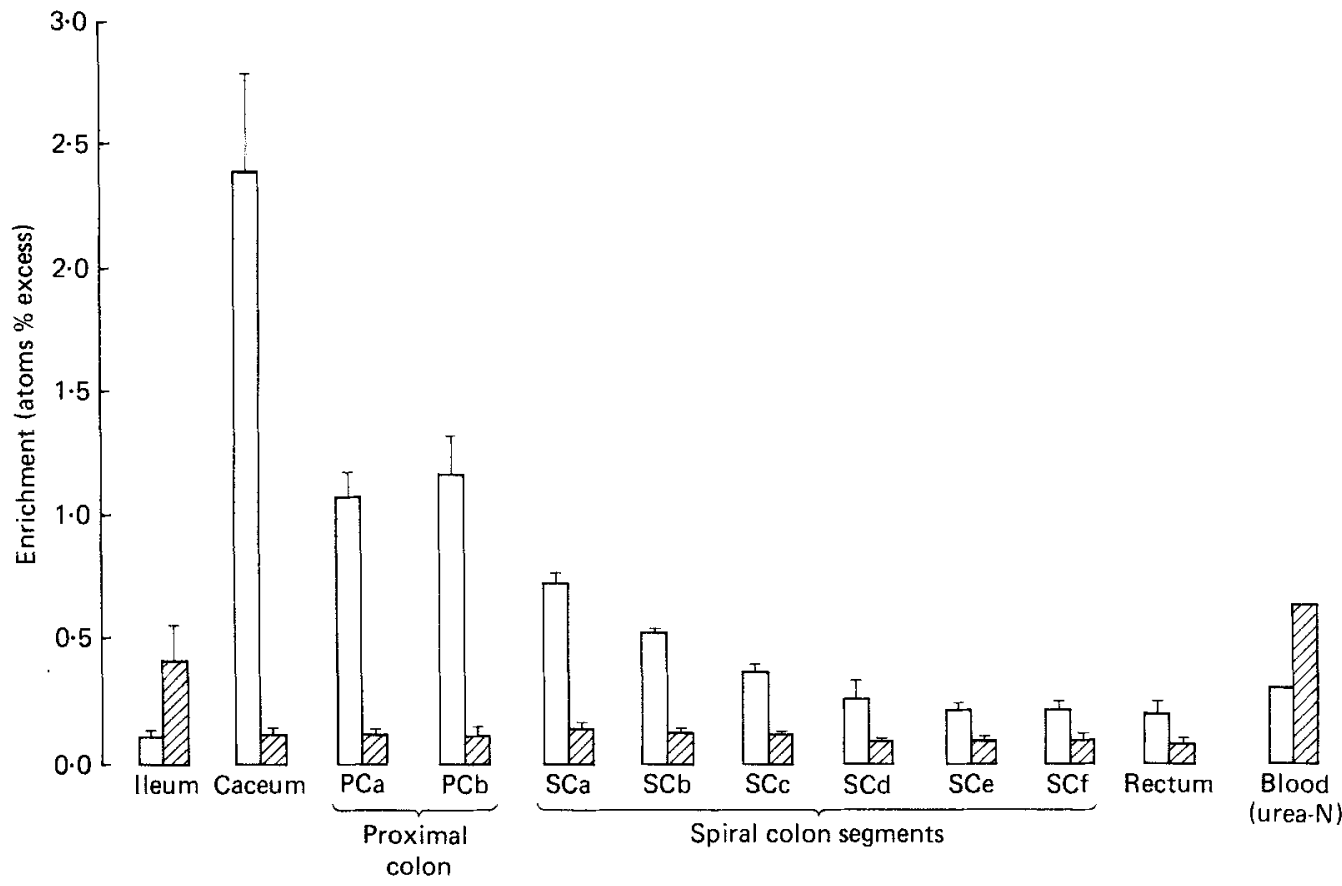

Fig. 1. Plateau enrichment of ammonia-nitrogen (atoms \% excess) in digesta from the ileum and segments of the large intestine, and of blood urea- $\mathrm{N}$ in sheep during a continuous infusion $\left(5 \mathrm{mg}\right.$ atoms $\left.{ }^{15} \mathrm{~N} / \mathrm{d}\right)$ of $\left({ }^{15} \mathrm{NH}_{4}\right)_{2} \mathrm{SO}_{4}$ into the caecum (Expt 1, $\square$ ) or of [ $\left.{ }^{15} \mathrm{~N}\right]$ urea into the blood (Expt 2, 逐). Mean values, with their standard errors represented by vertical bars, are given.

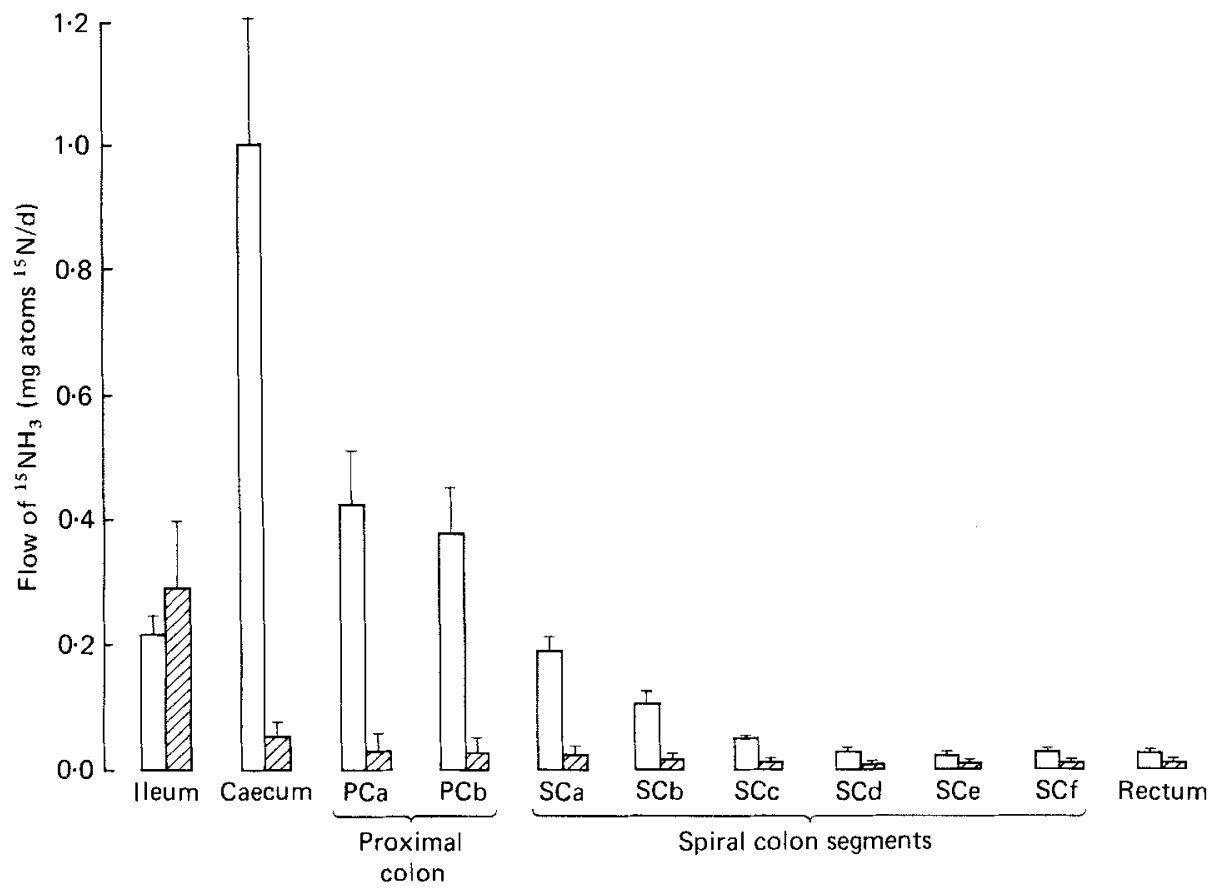

Fig. 2. Flows of ${ }^{15} \mathrm{NH}_{3}\left(\mathrm{mg}\right.$ atoms $\left.{ }^{15} \mathrm{~N} / \mathrm{d}\right)$ in the ileum and segments of the large intestine calculated from plateau enrichments (see Fig. 1) and corresponding rates of ammonia flow at the end of a continuous infusion into the caecum of $\left({ }^{15} \mathrm{NH}_{4}\right)_{2} \mathrm{SO}_{4}$ (Expt 1, $\square$ ) or $\left[{ }^{15} \mathrm{~N}\right]$ urea into the blood (Expt 2, 国). Mean values, with their standard errors represented by vertical bars, are given. 


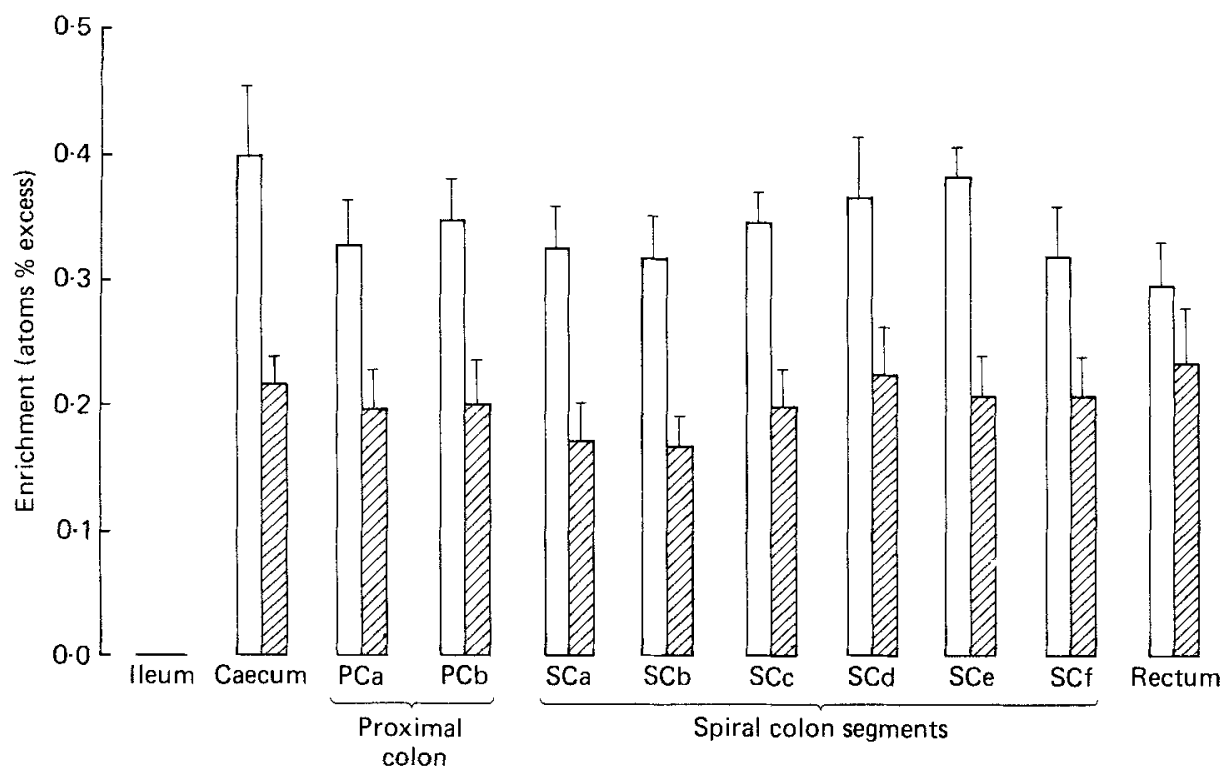

Fig. 3. The plateau enrichments (atoms \% excess) of microbial nitrogen ( $\square$ ) and of non-urea non-ammonia- $\mathrm{N}$ ( in segments of the large intestine during a continuous infusion ( $5 \mathrm{mg}$ atoms ${ }^{15} \mathrm{~N} / \mathrm{d}$ ) of $\left({ }^{15} \mathrm{NH}_{4}\right)_{2} \mathrm{SO}_{4}$ into the caecum (Expt 1). Mean values, with their standard errors represented by vertical bars, are given.

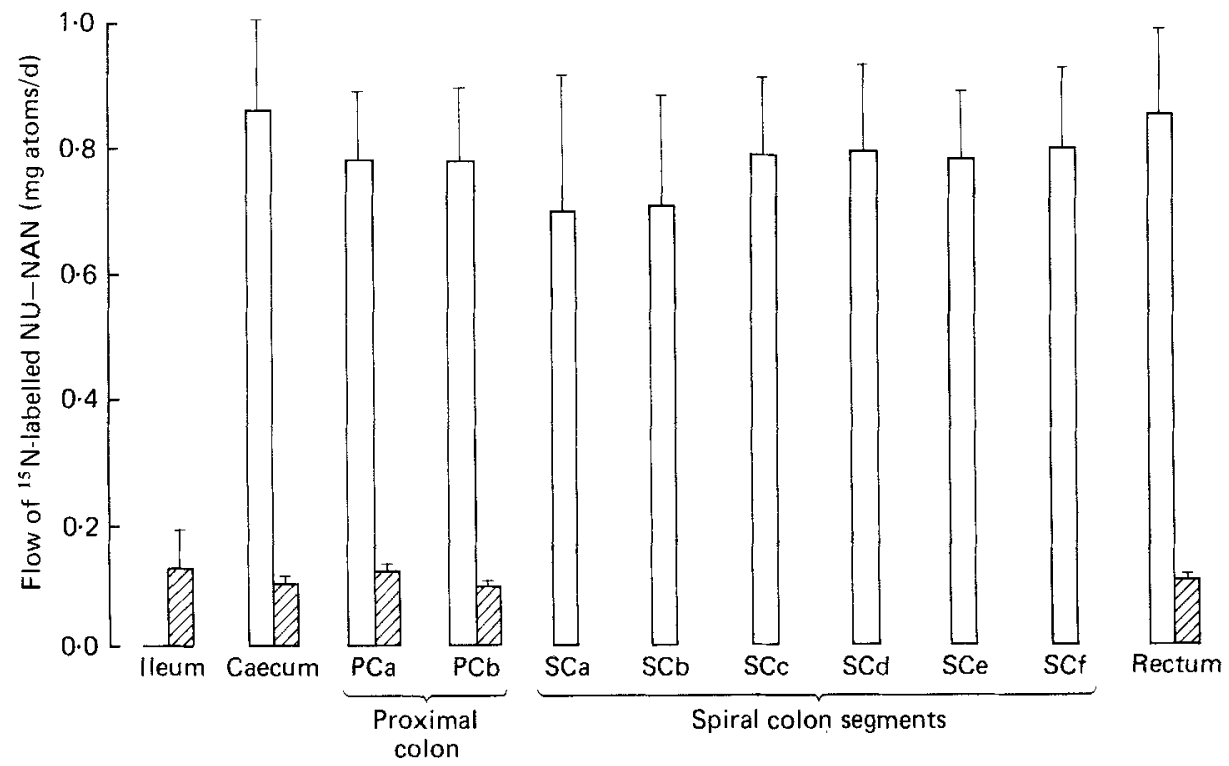

Fig. 4. The flow of ${ }^{15} \mathrm{~N}$-labelled non-urea non-ammonia-nitrogen (NU-NAN; $m g$ atoms ${ }^{15} \mathrm{~N} / \mathrm{d}$ ) in the ileum and in segments of the large intestine during continuous infusion $\left(5 \mathrm{mg}\right.$ atoms $\left.{ }^{15} \mathrm{~N} / \mathrm{d}\right)$ of $\left({ }^{15} \mathrm{NH}_{4}\right)_{2} \mathrm{SO}_{4}$ into the caecum (Expt $\left.1, \square\right)$ or $\left[{ }^{15} \mathrm{~N}\right]$ urea into the blood (Expt 2, Mean values, with their standard errors represented by vertical bars, are given. 
contributed $14-34 \%$ of the $\mathrm{N}$ in the caecal ammonia pool and $9-14 \%$ of that in the rumen ammonia pool (Table 1).

Kinetics of ${ }^{15} N$ in microbial $N$ and $N U-N A N$

The plateau enrichments of NU-NAN and microbial N in the isolated segments of the large intestine during Expt 1 are given in Fig. 3 and the flows of ${ }^{15} \mathrm{~N}$ in NU-NAN during Expts 1 and 2 in Fig. 4. There were no significant differences in enrichments or flows of NU-NAN in the different segments of the large intestine. During the intra-caecal infusion of $\left({ }^{15} \mathrm{NH}_{4}\right)_{2} \mathrm{SO}_{4}$, negligible amounts of recycled ${ }^{15} \mathrm{~N}$ were present in undigested rumen microbes or endogenous secretions reaching the ileum (Fig. 3). There was a significant $(P<0.05)$ decrease in microbial $\mathrm{N}$ enrichment between the caecum and the rectum.

The flow of microbial N out of the caecum $(3.60 \mathrm{~g} \mathrm{~N} / \mathrm{d})$ was $57 \%$ of the total flow of NU-NAN from this organ (Table 1); the rate of excretion of microbial $\mathrm{N}$ in faeces was not significantly different from that passing out of the caecum.

\section{DISCUSSION}

Tracer kinetics in the caecum and proximal colon

The enrichment of ammonia- $\mathrm{N}$ in the caecum was significantly higher than that in the proximal colon when $\left({ }^{15} \mathrm{NH}_{4}\right)_{2} \mathrm{SO}_{4}$ was infused into the caecum indicating that ammonia in these gut segments did not form one kinetic entity. In contrast, Dixon et al. (1982) found that the digesta in the caecum and proximal colon were homogenous with respect to ${ }^{51} \mathrm{Cr}$-EDTA. Thus ${ }^{51} \mathrm{Cr}$-EDTA appeared to be homogenous in a larger volume of digesta than ${ }^{15} \mathrm{NH}_{3}$, the difference being approximately equal to the volume of digesta in the proximal colon. Calculations based on the results of ${ }^{15} \mathrm{NH}_{3}$ infusions into and sampling from only the caecal ammonia pool would therefore be likely to underestimate the entry of ammonia in both the caecum and proximal colon. In the present study, however, the caecum and proximal colon were sampled separately. The similarity of the enrichments in the proximal colon segments $\mathrm{a}$ and $\mathrm{b}$ ( $\mathrm{PCa}$ and $\mathrm{PCb}$ respectively) suggested that a single ammonia pool may have occurred in the proximal colon.

\section{Assumptions for the model}

The results of the present study were used to develop a quantitative model of the flows of $\mathrm{N}$ in digesta and across the wall of the large intestine (Fig. 5). This model depends on a number of assumptions: First, although measurements of flows of $\mathrm{N}$ in the gut during slaughter experiments may be biased owing to the effects of mucosal shedding, this problem is unlikely to have influenced the results of the present study for reasons discussed by Dixon $\&$ Nolan (1982). Second, although about $16 \%$ of the infused ${ }^{15} \mathrm{~N}$ was incorporated into micro-organisms in the caecum (the NU-NAN fraction), it is not likely that the resulting ${ }^{15} \mathrm{~N}$-labelled amino acids (or nucleic acids) were absorbed as such from the large intestine (Ulyatt et al. 1975; Hoover, 1978). It was therefore assumed that ${ }^{15} \mathrm{~N}$ was absorbed from the large intestine only as ammonia and entered only in urea, i.e. NU-NAN that entered through the gut wall was not labelled. Some NU-NAN in tissues (e.g. epithelial cells and glucosamine in mucins) might be expected to have become slightly labelled. However, during Expt 1 any enrichment of NU-NAN in ileal digesta (that would have contained endogenous NU-NAN) was undetectable. Third, it was assumed for any $\mathrm{N}$ pool, that steady-state conditions applied, i.e. $\mathrm{N}$ inflows equalled $\mathrm{N}$ outflows. Fourth, in common with previous modelling studies in these laboratories (Nolan et al. 1976), results from experiments with two groups of sheep were combined to construct the model. The similarities in the caecal ammonia, blood urea and rumen ammonia concentrations (Table 1) suggested that there 


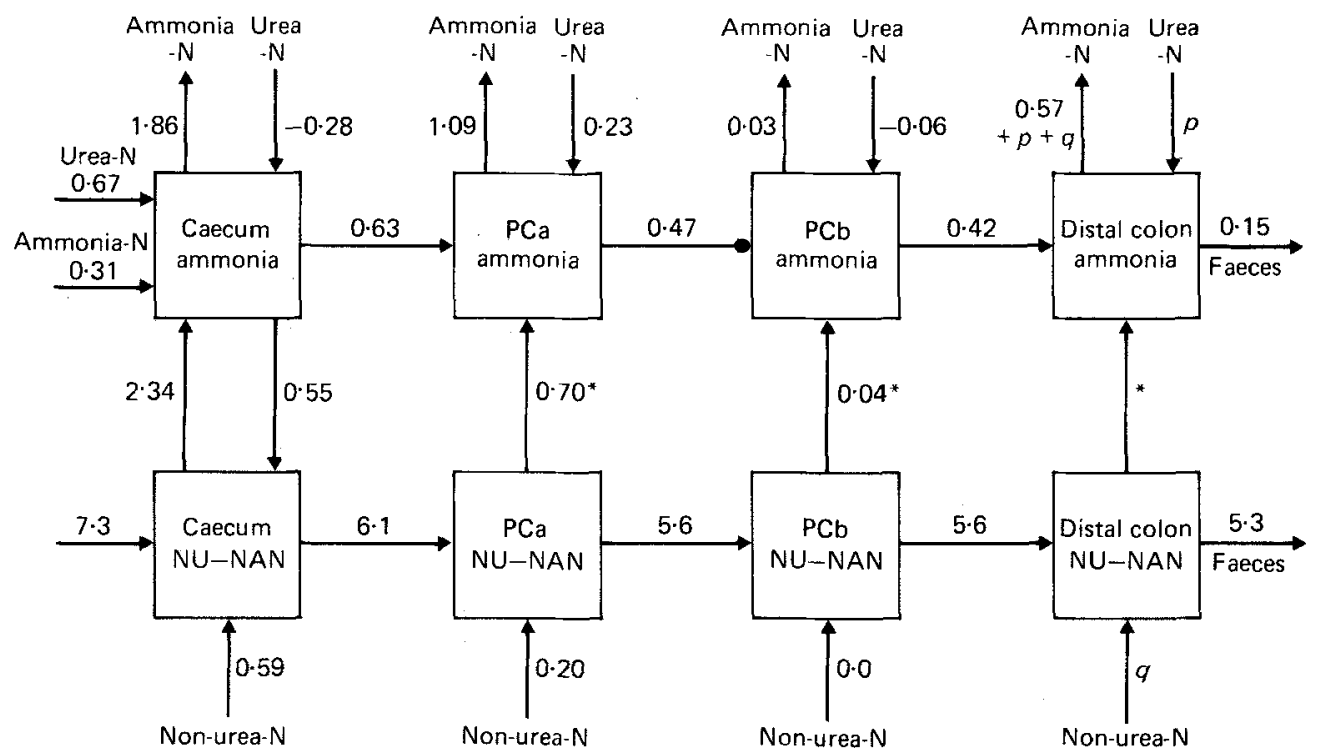

Fig. 5. An eight-pool model representing flows of nitrogen $(\mathrm{g} \mathrm{N} / \mathrm{d}$ ) entering and leaving ammonia and non-urea non-ammonia-N (NU-NAN) pools in segments of the large intestine including proximal colon segments $\mathrm{a}$ and $\mathrm{b}$ (PCa and $\mathrm{PCb}$ respectively). The distal parts of the colon and the rectum have been represented as one pool; flows designated as $p$ and $q$ were not calculated in this model, but represent entry of endogenous urea- $\mathrm{N}$ and non-urea- $\mathrm{N}$ respectively. Flows were calculated from the mean results of Expts 1 and 2. * Two-way flows; net flows given.

were no important differences between the groups of sheep in each experiment and thus the amalgamation of results seemed justifiable.

The small negative values for endogenous urea secretion in the large intestine obtained when solving the model (Fig. 5) are probably partly the result of amalgamating results of different experiments. However the estimates of endogenous-urea-transfer through the wall of the caecum and proximal colon indicate that the amounts of ammonia derived from endogenous urea were negligible relative to the amounts of ammonia absorbed.

\section{Kinetics of ammonia}

Values for the caecal pools in Fig. 5 were calculated as follows. Urea-N and ammonia-N entered the caecum from the ileum $(0.98 \mathrm{~g} / \mathrm{d})$ and ammonia-N also flowed $(0.63 \mathrm{~g} / \mathrm{d})$ from the caecum into the proximal colon (the PCa pool). Solution of equations based on ${ }^{15} \mathrm{~N}$ flows (p. 760) indicated that $1.86 \mathrm{~g}$ ammonia-N/d was absorbed and a small negative amount of urea $(-0.28 \mathrm{~g} \mathrm{~N} / \mathrm{d})$ was apparently derived from blood. A net amount of $1.79 \mathrm{~g}$ caecal ammonia/d was therefore apparently derived from the caecal NU-NAN pool. To balance inflows and outflows for the caecal NU-NAN pool, 0.59 gendogenous non-urea-N/d must have entered this pool. Since $0.55 \mathrm{~g}$ ammonia/d was incorporated into microbial $\mathrm{N}$ (Table 1), and hence into the NU-NAN pool in the caecum, the total degradation of NU-NAN to ammonia in the caecum was $2.34(1.79+0.55) \mathrm{g} \mathrm{N} / \mathrm{d}$. Similar calculations were made for pools in the other gut segments that were sampled.

Approximately $4.1 \mathrm{~g}$ ammonia- $\mathrm{N} / \mathrm{d}$ was produced in the caecum and proximal colon; $3.1 \mathrm{~g} \mathrm{~N} / \mathrm{d}(76 \%)$ was derived from degradation of NU-NAN and $1.0 \mathrm{~g} \mathrm{~N} / \mathrm{d}(24 \%)$ from endogenous urea and ammonia entering in ileal digesta. Ammonia- $\mathrm{N}$ was extensively absorbed from the caecum $(1.86 \mathrm{~g} / \mathrm{d})$ and proximal colon $(1.12 \mathrm{~g} / \mathrm{d})$ and these were the major sites of ammonia absorption in the large intestine. Only $16 \%$ of the caecal ammonia 
$(0.55 \mathrm{~g} \mathrm{~N} / \mathrm{d})$ was incorporated into microbial $\mathrm{N}$ and $11 \%$ passed into the distal colon in fluids.

Although there was insufficient information to quantitate fully the model of the spiral and descending colon, it was possible to obtain a minimum estimate of ammonia entry. As the enrichment of the ammonia in the rectum was one-sixth of that passing out of the proximal colon (PCb) segment, at least six times the rectal flow of ammonia-N/d (i.e. $6 \times 0.15=0.90 \mathrm{~g}$ ammonia- $\mathrm{N} / \mathrm{d}$ ) must have been produced from sources of unlabelled $\mathrm{N}$ such as endogenous and digesta NU-NAN between these sites. The gradual decrease in the rate of flow of ${ }^{15} \mathrm{NH}_{3}$ between the proximal colon and the rectum indicate that absorption of ammonia also occurred simultaneously and, therefore, the total entry of ammonia- $\mathrm{N}$ was in excess of $0.9 \mathrm{~g} \mathrm{~N} / \mathrm{d}$; any inflow of endogenous urea (designated by $p$ in the eight-pool model but not estimated in the present study) labelled with ${ }^{15} \mathrm{~N}$ would further increase this value.

The total amount of ammonia absorbed from the large intestine was at least $3.88 \mathrm{~g} \mathrm{~N} / \mathrm{d}$, or at least $1.0 \mathrm{~g} \mathrm{~N} / \mathrm{d}$ more than the net absorption of $2.83 \mathrm{~g} \mathrm{~N} / \mathrm{d}$. If inputs of endogenous non-urea- $\mathrm{N}$ in the spiral and descending colon were substantial, or if endogenous urea were transferred in appreciable amounts into the distal part of the large intestine (Nolan et al. 1976), then this difference between apparent and actual absorption of ammonia would have been greater than $1.0 \mathrm{~g} \mathrm{~N} / \mathrm{d}$. Net disappearance of total $\mathrm{N}$ between the ileum and the rectum in the present study was therefore considerably less than total ammonia absorption.

The observation that a substantial percentage (9-19) of plasma urea was derived from caecal ammonia is in agreement with Hecker $(1971 b)$ and Nolan et al. (1976). In common. with previous studies with sheep given chopped lucerne hay (Nolan \& Leng, 1972; Nolan et al. 1976; Kennedy \& Milligan, 1977), only 9-14\% of rumen ammonia-N was derived from endogenous urea- $\mathrm{N}$ and thus caecal ammonia contributed less than $3 \%$ of the $\mathrm{N}$ present in rumen ammonia. Under conditions where extensive transfer of endogenous urea to the rumen occurs (Kennedy \& Milligan, 1980), ammonia from the large intestine may contribute more substantially to rumen microbial protein synthesis.

\section{Endogenous urea- and non-urea- $N$}

The NU-NAN entering in ileal digesta and derived from endogenous secretions was the source of $76 \%$ of the total entry of ammonia in the caecum and proximal colon; endogenous urea and ammonia entering in ileal digesta accounted for the remaining $24 \%$. Hecker (1971 a) showed that the rate of degradation of several proteins (gelatin, casein, fibrin, glutin) in vitro was $50-100 \%$ greater in caecal fluid than in rumen fluid, while the rate of production of ammonia from casein hydrolysate and urea was similar in both fluids. Thus it appears that the necessary levels of enzyme activity are present in caecal digesta to account for the levels of proteolysis and deamination suggested in the model.

That there was negligible transfer of urea from the blood across the wall of the caecum and proximal colon in the sheep in the present study was unexpected, since results from sheep and goats prepared with caecal pouches (Houpt, 1963; see Chalmers et al. 1976) or with parts of the large intestine occluded by inflated balloons (Engelhart \& Hinderer, 1976) indicate that direct transfer of blood urea can occur. Thornton et al. (1970) and Ørskov et al. (1970) reported net gains of 0.7 and $1.6 \mathrm{~g} \mathrm{~N} / \mathrm{d}$ respectively between the ileum and rectum, with a concomitant reduction in urinary excretion, when a readily-fermentable energy source was infused into the ileum. They postulated that endogenous urea- $\mathrm{N}$ entered the large intestine and, after incorporation into microbial protein, was excreted in faeces. The present study suggests that at least part of this gain in $\mathrm{N}$ could have been due to microbial incorporation of ammonia derived from endogenous non-urea- $N$ (e.g. from secreted mucins and sloughed epithelial cells), as opposed to transfer of blood urea-N through the wall of the large intestine. There are high concentrations of secretory cells in 
the spiral and descending colon (Ulyatt et al. 1975) and the endogenous non-urea-N secretion into the whole of the large intestine in the present experiment may have been considerably more than the $0.8 \mathrm{~g} \mathrm{~N} / \mathrm{d}$ estimated to have been secreted into the caecum and proximal colon. The only other estimates of endogenous non-urea-N input to the large intestine appear to be those of Kay (1969) who found that $0 \cdot 1-0 \cdot 2 \mathrm{~g} \mathrm{~N} / \mathrm{d}$ were secreted into isolated pouches in the caecum and the spiral colon.

\section{Synthesis of micro-organisms}

Estimation of the microbial $\mathrm{N}$ in the NU-NAN in digesta from the large intestine was based on the methods described by Roberts \& Miller (1969), Beever et al. (1974) and Hume (1974) for estimating the microbial $\mathrm{N}$ in abomasal or duodenal digesta. However, the microbial materials isolated from caecal digesta were probably a mixture of bacteria synthetized in the caecum and undigested rumen microbes. The method used would therefore have identified microbial $\mathrm{N}$ from both of these sources. The results of Expt 1 indicated that about half the total NU-NAN (3.6 (SE 0.68) g N/d) that flowed out of the caecum was microbial $\mathrm{N}$. Since the flow of undigested rumen microbes into the caecum was probably about $3 \mathrm{~g} \mathrm{~N} / \mathrm{d}$ (assuming that $10 \mathrm{~g}$ microbial N/d flowed from the rumen and was $70 \%$ digestible in the small intestine; Nolan, 1975) there was apparently little net synthesis of microbial $\mathrm{N}$ in the caecum, i.e. perhaps $3.6-3.0=0.6 \mathrm{~g} \mathrm{~N} / \mathrm{d}$ or $6 \%$ of that occurring in the rumen.

The estimated $18 \%$ decrease in flow of ${ }^{15} \mathrm{~N}$-labelled NU-NAN between the ileum and the caecum in Expt 2 suggested that there was at least some digestion in the caecum of microbial $\mathrm{N}$ originating in the rumen, although total turnover of microbial $\mathrm{N}$ may have been considerably greater than $18 \%$ if substantial reincorporation of ${ }^{15} \mathrm{~N}$-labelled products of microbial degradation into newly-synthesized microbes occurred. The finding that there was no decrease in the rate of flow of ${ }^{15} \mathrm{~N}$-labelled NU-NAN between the caecum and rectum in both Expts 1 and 2 indicated that there was little absorption of microbial constituents distal to the caecum. These results suggest that digestion and absorption of microbial materials was less than that measured by Yang et al. (1972) and Judson et al. (1975) who found $30-42 \%$ of ${ }^{14} \mathrm{C}$-labelled and ${ }^{35} \mathrm{~S}$-labelled bacteria (labelled in vitro and administered into the caecum) were apparently digested in the large intestine. However, the in vitro incubations used to label the cells may have increased the susceptibility of the bacteria to lysis in those experiments; in the present study the rumen microbial debris, after passing through the small intestine, may have been relatively resistant to further degradation. The present results provide support for the view that negligible amounts of amino acids are absorbed from the large intestine of sheep.

\section{CONCLUSIONS}

The study reported here indicates that, although endogenous urea transfer across the wall of the large intestine was negligible, there were substantial inputs of endogenous non-urea-N. The caecum and proximal colon were the major sites of the ammonia entry in the large intestine. Most of this ammonia was absorbed but in these sheep given a high- $\mathrm{N}$ roughage diet this ammonia made only a small contribution $(14 \%)$ to urea synthesis in the body. About half the NU-NAN flowing from the caecum was in microbial substances and probably the majority was of rumen origin. There was negligible apparent digestion of either NU-NAN or microbial $\mathrm{N}$ distal to the caecum.

The financial assistance of the Australian Wool Corporation is gratefully acknowledged. The authors wish to thank Professor R. A. Leng, and Drs J. F. Hecker and V. J. Bofinger for helpful discussions. 


\section{REFERENCES}

Beever, D. E., Harrison, D. G., Thomson, D. J., Cammell, S. B. \& Osbourn, D. F. (1974). British Journal of Nutrition 32, 99-112.

Beever, D. E., Thomson, D. J. \& Cammell, S. B. (1976). Journal of Agricultural Science, Cambridge 86, $443-452$.

Beever, D. E., Thomson, D. J., Cammell, S. B. \& Harrison, D. G. (1977). Journal of Agricultural Science, Cambridge 88, 61-70.

Chalmers, M. I., Grant, I. \& White, F. (1976). In Protein Metabolism and Nutrition, pp. 159-179 [D. J. A. Cole, K. N. Boorman, P. J. Buttery, D. Lewis, R. J. Neale and H. Swan, editors]. London: Butterworths.

Dixon, R. M. \& Nolan, J. V. (1982). British Journal of Nutrition 47, 289-300.

Dixon, R. M., Nolan, J. V. \& Milligan, L. P. (1982). British Journal of Nutrition 47, 301-309.

Elsden, S. R., Hitchcock, M. W. S., Marshall, R. A. \& Phillipson, A. T. (1946). Journal of Experimental Biology 22, 191-202.

Engelhardt, W. Von \& Hinderer, S. (1976). In Tracer Studies on Non-protein Nitrogen for Ruminants, vol. 3, pp. 57-58. Vienna: International Atomic Energy Agency.

Hecker, J. F. (1971 a). British Journal of Nutrition 25, 85-95.

Hecker, J. F. (1971 b). British Journal of Nutrition 26, 135-145.

Hoover, W. H. (1978). Journal of Animal Science 46, 1789-1799.

Houpt, T. R. (1963). American Journal of Physiology 205, 1144-1150.

Hume, I. D. (1974). Australian Journal of Agricultural Research 25, 155-165.

Judson, G. J., Abdelsamie, R. \& Bird, R. B. (1975). Australian Journal of Agricultural Research 26, $743-749$.

Kay, R. N. B. (1969). Proceedings of the Nutrition Society 28, 140-150.

Kempton, T. J., Nolan, J. V. \& Leng, R. A. (1979). British Journal of Nutrition 42, 303-315.

Kennedy, P. M. \& Milligan, L. P. (1977). Proceedings of the Nutrition Society 36, 53A.

Kennedy, P. M. \& Milligan, L. P. (1980). Canadian Journal of Animal Science 60, 205-221.

Nolan, J. V. (1975). In Digestion and Metabolism in the Ruminant, pp. 416-431 [I. W. McDonald and A. C. I. Warner, editors]. Armidale, Australia: University of New England Publishing Unit.

Nolan, J. V. \& Leng, R. A. (1972). British Journal of Nutrition 27, 177-194.

Nolan, J. V. \& Leng, R. A. (1974). Proceedings of the Nutrition Society 33, $1-9$.

Nolan, J. V., Norton, B. W. \& Leng, R. A. (1976). British Journal of Nutrition 35, 127-147.

Ørskov, E. R., Fraser, C., Mason, V. C. \& Mann, S. O. (1970). British Journal of Nutrition 24, 671-682.

Roberts, S. A. \& Milier, E. L. (1969). Proceedings of the Nutrition Society 28, 32A.

Snedecor, G. W. \& Cochran, W. G. (1967). Statistical Methods, 6th ed. Ames, Iowa, USA: Iowa State University Press.

Thornton, R. F., Bird, P. R., Somers, M. \& Moir, R. J. (1970). Australian Journal of Agricultural Research 21, 345-354.

Ulyatt, M. J., Dellow, D. W., Reid, C. S. W. \& Bauchop, T. (1975). In Digestion and Metabolism in the Ruminant, pp. 119-133 [I. W. McDonald and A. C. I. Warner, editors]. Armidale, Australia: University of New England Publishing Unit.

Williams, V. J. (1965). Australian Journal of Agricultural Research 16, 77-91.

Yang, M. G., Bergan, W. G., Sculthorpe, A. E. \& Michelsen, D. (1972). Proceedings of the Society of Experimental Biology and Medicine 139, 1312-1318. 